*УДК 657

Сидоренко Р.В., к.е.н., доцент

Кашик Ю.В.

Луцький національний технічний університет

\title{
ОРГАНІЗАЦІЯ ОБЛІКОВОГО ПРОЦЕСУ ВИТРАТ ЛІСОВИХ ГОСПОДАРСТВ ЗА ВІТЧИЗНЯНИМИ ТА МІЖНАРОДНИМИ СТАНДАРТАМИ
}

У статті висвітлені питання організації обліку витрат лісових господарств за міжнародними та національними стандартами. Авторами виділено існуючі відмінності щодо обліку і визнання витрат та готової продукції лісогосподарських підприємств.

Ключові слова: організація обліку, витрати, лісове господарство, готова продукція, міжнародні стандарти.

Sydorenko R., Kachyk Yu.

\section{ORGANIZATION OF ACCOUNTING PROCESS FOR EXPORT FOR FORESTS UNDER DOMESTIC AND INTERNATIONAL STANDARDS}

Forestry plays a significant role in the development of the Ukrainian economy. Forestry products of Ukraine are competitive both in their state and abroad. In connection with the gradual transition of national accounting legislation to international standards, there is an urgent need to study the existing differences regarding the specifics of accounting organization in forest enterprises.

Recent changes in accounting legislation, in particular the Law of Ukraine "On Accounting and Financial Reporting in Ukraine", make it possible to understand that there is a continuing trend towards approximation of requirements and provisions of domestic and international accounting and reporting legislation.

Currently only large enterprises are included in this list. But the further list of enterprises that will report on international standards will gradually increase and will be referred to medium-sized enterprises to which category, in its bulk, are forest enterprises.

Forestry is not attracting investors, because in order to make a profit for a certain time, and they want to get quick return on investment, the problem of attracting investors to forestry and assessing the efficiency of investments is extremely relevant.

In our opinion, in order to increase the contributions of foreign investors to the forestry, it is necessary to increase their investment attractiveness and to improve certain areas of forest policy, which will enable to obtain credit and tax preconditions for fund-

* Сидоренко Р.В., Кашик Ю.В. 
ing projects for the reproduction of forest resources. Increasing the investment attractiveness of forestry business, especially for foreign investors, can be by means of accounting and financial reporting according to international standards, that is, in the "language" understood by foreign investors.

Summarizing the above information, it should be noted that the characteristics of forestry enterprises are not sufficiently reflected in national standards in international accounting and reporting.

Equivalence of forestry activities with agricultural standards in accounting standards is not feasible, as the characteristics of these industries are inherent to each other and can not be subject to the same accounting principles and methods.

In our opinion, it is advisable to develop a separate accounting standard, analogous to agriculture, which describes the procedure and basic principles of accounting for forestry activities: accounting for the costs of activities, the formation of the initial value of forestry products, the distribution of accumulated costs between different types of products, etc.

Key words: accounting, expenses, forestry, financial reporting, investments, international standards.

Сидоренко Р.В., Кашик Ю.В.

\section{ОРГАНИЗАЦИЯ УЧЕТНОГО ПРОЦЕСА ЗАТРАТ ЛЕСНЫХ ХОЗЯЙСТВ ПО НАЦИОНАЛЬНЫМ И МЕЖДУНАРОДНЫМ СТАНДАРТАМ}

В статье освещены вопросы организации учета затрат лесных хозяйств по международным и национальным стандартам. Авторами выделены существующие различия по учету и признанию расходов и готовой продукции лесохозяйственных предприятий.

Ключевые слова: организация учета, расходы, лесное хозяйство, готовая продукция, международные стандарты.

\section{Постановка проблеми у загальному вигляді та її зв'язок 3} важливими науковими і практичними завданнями. Лісове господарство відіграє вагому роль у розвитку української економіки. Лісогосподарська продукція України є конкурентоспроможною як в своїй державі, так і за кордоном.

Загальна площа лісових ділянок, що належить до лісового фонду України, становить 10,4 млн. га, в тому числі вкриті лісовою рослинністю 9,6 млн. га. Лісистість України становить 15,9\%. Хоч і ми знаходимося в десятці за загальною площею лісів, але лісистість України (\% площі країни, що зайнятий лісами), в порівнянні 3 ін- 
шими країна, найнижча. Показники лісистості в країнах Європи наведено у табл. 1.

Таблиця 1

Показники лісистості в країнах Свропи за 2016 рік [4]

\begin{tabular}{|c|c|c|c|c|}
\hline $\begin{array}{c}\text { № } \\
\text { п/п }\end{array}$ & Країна & $\begin{array}{c}\text { Загальна площа } \\
\text { території країни, } \\
\text { тис. га }\end{array}$ & $\begin{array}{c}\text { Площа вкритих } \\
\text { лісом земель, } \\
\text { тис. га }\end{array}$ & $\begin{array}{c}\text { Лісис- } \\
\text { тість (\%) }\end{array}$ \\
\hline 1 & Швеція & 45218 & 30625 & 67,7 \\
\hline 2 & Іспанія & 50596 & 27748 & 54,8 \\
\hline 3 & Фінляндія & 33814 & 23116 & 68,4 \\
\hline 4 & Туреччина & 77945 & 21702 & 27,8 \\
\hline 5 & Франція & 54919 & 17572 & 32,0 \\
\hline 6 & Норвегія & 32376 & 12384 & 38,3 \\
\hline 7 & Німеччина & 35702 & 11076 & 31,0 \\
\hline 8 & Італія & 30132 & 10916 & 36,2 \\
\hline 9 & Україна & 60355 & 9573,9 & 15,9 \\
\hline 10 & Польща & 31268 & 9319 & 29,8 \\
\hline
\end{tabular}

У зв'язку з поступовим переходом національного облікового законодавства на міжнародні стандарти постає актуальна необхідність у дослідженні існуючих відмінностей, щодо особливості організації обліку в лісогосподарських підприємствах.

Аналіз останніх досліджень у яких започатковано вирішення проблеми. Проблеми організації обліку витрат лісового господарства досліджували вітчизняні вчені такі, як: В.О. Озеран, Т.М. Сторожук, М.Ю. Чік та інші. Однак, поступове зближення вимог національних та міжнародних стандартів обліку та звітності потребує проведення подальших досліджень.

Цілі статті. Метою написання даної статті є дослідження існуючих відмінностей щодо ведення обліку витрат та готової продукції у лісових господарствах за вітчизняними та міжнародними стандартами.

Виклад основного матеріалу дослідження 3 обгрунтуванням отриманих наукових результатів. Лісове господарство - це галузь промисловості, яка веде облік лісів і диких тварин, охороняє, відновлює їх, а також продає свою продукцію населенню i 
Економічні науки". - Серія "Облік і фінанси". - Випуск 15 (57). - 2018.

іншим промисловим покупцям. Показники діяльності лісової галузі України наведено у табл. 2.

Таблиця 2

Основні показники лісогосподарської діяльності в Україні за 2012-2016 роки [4]

\begin{tabular}{|c|c|c|c|c|c|}
\hline \multirow{2}{*}{ Назва показника } & \multicolumn{5}{|c|}{ Роки } \\
\cline { 2 - 6 } & 2012 & 2013 & 2014 & 2015 & 2016 \\
\hline Відтворення лісів, тис. га & 70,1 & 67,7 & 58,0 & 60,4 & 63,2 \\
\hline $\begin{array}{c}\text { Заготівля ліквідної дереви- } \\
\text { ни, тис. м }\end{array}$ & 417,0 & 415,4 & 382,6 & 399,3 & 386,4 \\
\hline $\begin{array}{c}\text { Експорт деревини і виробів } \\
\text { з деревини, млн. дол. США }\end{array}$ & 17507 & 18022 & 18333 & 19268 & 19606 \\
\hline $\begin{array}{c}\text { Частка в загальному обсязі } \\
\text { експорту деревини і виро- } \\
\text { бів з деревини, \% }\end{array}$ & 1,5 & 1,8 & 2,3 & 2,9 & 3,1 \\
\hline $\begin{array}{c}\text { Імпорт деревини і виробів } \\
\text { з деревини, млн. дол. США }\end{array}$ & 369,6 & 416,0 & 294,5 & 148,2 & 196,7 \\
\hline $\begin{array}{c}\text { Частка в загальному обсязі } \\
\text { імпорту деревини і виробів } \\
\text { з деревини, \% }\end{array}$ & 0,4 & 0,5 & 0,5 & 0,4 & 0,5 \\
\hline
\end{tabular}

Однією з головних проблем діяльності галузі є незаконна вирубка лісів та неповний облік (заниження кількості) заготовленої сировини. За Україною закріпився статус одного з найбільших експортерів необробленої деревини в Європі. В 2015 році було незаконно вирубано 24 тис. кубів лісу, в першому півріччі 2016 року обсяг незаконних рубок по галузі склав 15,8 тис. кубів, що на 36\% більше, ніж у відповідному періоді минулого року.

Для усунення цього у 2015 році Верховною Радою України було внесено зміни до Закону України "Про особливості державного регулювання діяльності суб'єктів підприємницької діяльності, пов'язаної з реалізацією та експортом лісоматеріалів", щодо тимчасової заборони експорту лісоматеріалів у необробленому вигляді, який: 
1. Посилює адміністративну відповідальність за незаконну вирубку лісу.

2. Встановлює обмеження внутрішнього споживання необроблених лісоматеріалів у розмірі 25 млн. куб. м. Ця норма необхідна для приведення законодавства у відповідність з вимогами СОТ.

3. Забороняється строком на вісім років вивезення за межі митної території України паливної деревини (дров). Держава заборонила вивезення деревини будь-яких сортів, крім сосни. 31 січня 2017-го заборонено експортувати і їі. [2].

Заборона вивезення необробленої деревини за межі України створює необхідність переробляти сировину на вітчизняних підприємствах. Тобто, збільшує кількість таких підприємств та чисельність працюючих на них, продукує нові робочі місця.

Проте у межах економічної співпраці України та Свропейського Союзу, СС вимагає зняття мораторію на експорт необробленої деревини. Українські виробники наголошують на тому, що зняття обмежень на експорт призведе до дефіциту лісосировини та зупинки понад 90\% підприємств, які виробляють фанеру, шпон, фланель, меблі та паркет.

Окрім загальногалузевих проблем, що потребують негайного вирішення, гостро стоять і питання щодо правильності та точності відображення вартості витрат на здійснення діяльності лісових господарств та обліку їх готової продукції.

Останні зміни облікового законодавства, зокрема Закону України «Про бухгалтерський облік та фінансову звітність в Україні» дають змогу зрозуміти, що і далі триває тенденція до зближення вимог та положень вітчизняного і міжнародного законодавства щодо обліку та звітності.

На сьогоднішній день, згідно Закону України «Про бухгалтерський облік та фінансову звітність в Україні», складання фінансової та консолідованої фінансової звітності за міжнародними стандартами визначене обов'язковим для наступних категорій підприємств:

1) підприємства, що становлять суспільний інтерес. 
Економічні науки". - Серія "Облік і фінанси". - Випуск 15 (57). - 2018.

2) великі підприємства;

3) публічні акціонерні товариства;

4) підприємства, які здійснюють діяльність 3 видобутку корисних копалин загальнодержавного значення;

5) підприємства що провадять господарську діяльність за наступними видами:

- надання фінансових послуг, крім страхування та пенсійного забезпечення;

- недержавне пенсійне забезпечення;

- допоміжна діяльність у сферах фінансових послуг і страхування, за винятком допоміжної діяльності у сфері страхування та пенсійного забезпечення [1].

Але подальший перелік підприємств які будуть подавати звітність за міжнародними стандартами буде поступово збільшуватися і до них будуть відноситися середні підприємства до категорії яких, в своїй основній масі, відносяться лісогосподарські підприємства.

Лісове господарство не приваблює інвесторів, тому що для того щоб отримати прибуток необхідний певний час, а вони хочуть отримати швидко дохід від вкладеного капіталу, тому проблеми залучення інвесторів в лісове господарство та оцінка ефективності інвестицій є надзвичайно актуальними.

На нашу думку, щоб збільшити вклади іноземних інвесторів в лісові господарства необхідно підвищити їх інвестиційну привабливість та вдосконалити окремі ділянки лісової політики, що дадуть можливість одержати кредитні та податкові передумови для фінансування проектів відтворення лісових ресурсів. Підвищити інвестиційну привабливість лісогосподарського бізнесу, особливо для іноземних інвесторів, можна за допомогою ведення обліку та складання фінансової звітності за міжнародними стандартами, тобто, на «мові» зрозумілій для зовнішніх інвесторів.

Облік діяльності лісового господарства регламентується як загально-нормативними, так і галузевими нормативними актами. Основним 3 них $є$ «Інструкції з обліку продукції лісозаготівель, 
лісопиляння і деревообробки на підприємствах Державного комітету лісового господарства» [3].

Згідно цієї Інструкції лісові підприємства повинні вести облік виробництва на активному рахунку 23 «Виробництво» у розрізі наступних субрахунків:

1. 231 «Лісозаготівля» в розрізі видів деревини, що заготовляється;

2. 232 «Виробництво пиломатеріалів» в розрізі видів пиломатеріалів, що виробляється;

3. 233 «Послуги з розпилювання» (формується собівартість послуг з переробки сировини замовників і розрізі видів послуг);

4. 234 «Автотранспортні послуги» (формується собівартість автотранспортних послуг у розрізі видів послуг);

5. 235 «ннше виробництво» (передбачений для формування собівартості видів продукції, неврахованих вище);

6. 91 «Загальновиробничі витрати» (відображається інформація про витрати виробництва, які не можна безпосередньо віднести на конкретний вид продукції).

Чік М.Ю. висуває зовсім інший подхід відображення витрат на рахунку 23 «Виробництво». На іiї думку доцільно використовувати наступні субрахунки до рахунку 23 «Виробництво»:

1. 231 «Витрати на утримання незрілих біологічних активів, які оцінюються за первісною вартістю»;

2. 232 «Витрати на утримання довгострокових біологічних активів, які оцінюються за первісною вартістю»;

3. 233 «Витрати на лісозаготівлю»;

4. 234 «Транспортні витрати» [8].

Аналітика до рахунку 26 «Готова продукція», згідно вже згадуваної інструкції, має розподілятись наступним чином:

1) 261 «Готова продукція лісозаготівлі»:

- 261.1 «Готова продукція лісозаготівлі хвойних порід»

- 261.2 «Готова продукція лісозаготівлі м'яколистяних порід» 
- 261.3 «Готова продукція лісозаготівлі твердолистяних порід»

2) 262 «Пиломатеріли»:

- 262.1 «Пиломатеріали хвойних порід»

- 262.2 «Пиломатеріали м’яколистяних порід»

- 262.3 «Пиломатеріали твердолистяних порід».

Основною метою обліку витрат і собівартості продукції лісового підприємства є достовірне, своєчасне і повне відображення фактичних витрат, які пов'язані з виробництвом продукції, обчислення фактичної собівартості різних видів лісової продукції .

Витратам в міжнародних стандартах не приділяється окреме МСБО. Поняття витрат розкритті у МСБО 1 «Подання фінансових звітів», МСБО 2 «Запаси», МСБО 16 «Основні засоби», МСБО 18 «Дохід», МСБО 23 «Витрати на позики». Спираючись на вказані стандарти можна сказати що, витрати - це зменшення економічних вигод протягом облікового періоду у вигляді вибуття чи амортизації активів або у вигляді виникнення зобов'язань, результатом чого є зменшення власного капіталу, за винятком зменшення, пов'язаного з виплатами учасникам. Отже, підхід до поняття «витрати» як за національними, так і за міжнародними стандартами ідентичний.

У міжнародних стандартах відсутнє визначення терміну лісова діяльність. Лісова діяльність згідно міжнародних стандартів прирівнюється до сільськогосподарської діяльності. Згідно міжнародного стандарту бухгалтерського обліку 41 «Сільське господарство» сільськогосподарська діяльність - це управління суб'єктом господарювання біологічною трансформацією та збір врожаю біологічних активів для продажу чи для переробки в сільськогосподарську продукцію або в додаткові біологічні активи [5].

На думку Озеран В.О. та Чік М.Ю. віднесення лісового господарства до сільськогосподарської діяльності у МСБО 41 «Сільське господарство» є не зовсім коректним, оскільки лісове господарство є самостійною галуззю матеріального виробництва [6]. 
У табл. 3 подані приклади біологічних активів, сільськогосподарської продукції та продуктів, які є результатом їі переробки після збирання врожаю згідно міжнародного стандарту бухгалтерського обліку 41 «Сільське господарство». 3 даної таблиці ми бачимо що продукція лісового господарства прирівнюється до біологічних активів [4].

Таблиця 3

Приклади біологічних активів сільськогосподарської і лісової продукції

\begin{tabular}{|c|c|c|}
\hline Біологічні активи & $\begin{array}{c}\text { Сільськогосподарська } \\
\text { продукція }\end{array}$ & $\begin{array}{c}\text { Продукти, які є резуль- } \\
\text { татом переробки після } \\
\text { збирання врожаю }\end{array}$ \\
\hline Вівці & Вовна & Пряжа, килим \\
\hline $\begin{array}{c}\text { Дерева у лісопо- } \\
\text { садці }\end{array}$ & Зрубаний ліс & Лісоматеріали \\
\hline \multirow{2}{*}{ Рослини } & Бавовна & Нитки, одяг \\
\cline { 2 - 3 } & $\begin{array}{c}\text { Зібрана цукрова трос- } \\
\text { тина }\end{array}$ & Цукор \\
\hline Свині & Туші & $\begin{array}{c}\text { Ковбаса, розфасована } \\
\text { шинка }\end{array}$ \\
\hline Молочна худоба & Молоко & Сир \\
\hline Виноградники & Виноград & Вино \\
\hline Фруктові дерева & Зібрані фрукти & $\begin{array}{c}\text { Фрукти після перероб- } \\
\text { ки }\end{array}$ \\
\hline
\end{tabular}

Аналогічна ситуація і у вітчизняному обліку: при визнанні продукції лісогосподарських підприємств використовується методика прописана у П(С)БО 30 «Біологічні активи», що є аналогом МСБО 41 «Сільське господарство».

Висновки. Узагальнюючи наведену інформацію слід відмітити, що особливості діяльності лісогосподарських підприємств недостатньо відображені, що в національних, що у міжнародних стандартах обліку та звітності.

Прирівняння лісогосподарської діяльності до сільськогосподарської, в облікових стандартах, є недоцільним, оскільки прита- 
Економічні науки". - Серія "Облік і фінанси". - Випуск 15 (57). - 2018.

манні цим галузям особливості діяльності різняться між собою і до них не можуть застосовуватись однакові облікові принципи та методи.

На нашу думку доцільно розробити окремий обліковий стандарт, аналогічно до сільського господарства, в якому описати порядок та основні принципи обліку лісогосподарської діяльності: обліку витрат на здійснення діяльності, формування первісної вартості продукції лісового господарства, розподілу накопичених витрат між різними видами продукції тощо.

1. Закон України «Про бухгалтерський облік та фінансову звітність в Україні» [Електронний ресурс]. - Режим доступу: http://zakon3.rada.gov.ua/laws/ show/996-14.

2. Закон України «Про внесення змін до Закону України «Про особливості державного регулювання діяльності суб'єктів підприємницької діяльності пов'язаної з реалізацією та експортом лісоматеріалів» щодо тимчасової заборони експорту лісоматеріалів у необробленому вигляді» № 325-VIII від 09.04.2015p. [Електронний ресурс]: - Режим доступу: http://zakon.rada.gov. ua/laws/show/325-19.

3. Інструкція з обліку продукції лісозаготівель, лісопиляння і деревообробки на підприємствах Державного комітету лісового господарства України, затверджена наказом Держкомлісгоспу України від 19 грудня 2003 р. № 205.

4. Лісове господарство України - 2017 [Електронний ресурс]: - Режим доступу: http://dklg.kmu.gov.ua/forest/control/uk/index

5. Міжнародний стандарт бухгалтерського обліку 41 «Сільське господарство» [Електронний ресурс]. - Режим доступу: http://www.minfin.gov.ua/ control/ publish/article/main?art_id=92410\&cat_id=92408.

6. Озеран В.О. Вплив організаційно-технологічних особливостей лісового господарства на методику обліку та контролю витрат і калькулювання собівартості продукції / В. О. Озеран, М. Ю. Чік // Вісн. Нац. ун-ту «Львів. політехніка». 2009. - № 647. - С. 445-449.

7. Сторожук Т.М. Планування та облік недеревних лісових ресурсів / Т.М. Сторожук, Н.С. Дружинська // Науковий вісник Херсонського державного університету. Серія «Економічні науки». - 2016. - №16 (ч.4). - С. 137-140.

8. Положення (стандарт) бухгалтерського обліку 30 «Біологічні активи» [Електронний ресурс]. - Режим доступу: http://zakon.rada.gov.ua/laws/show/z1456-05.

9. Чік М.Ю. Аспекти побудови системи бухгалтерського обліку витрат на підприємствах лісового господарства [Текст] / М.Ю. Чік // Науковий вісник НЛТУ України. - 2012. - Вип. 22.10. - С. 194-198. 